\title{
KEBERADAAN HUKUM TANAH ADAT DALAM IMPLEMENTASI HUKUM AGRARIA
}

Oleh :

Nunuk Sulisrudatin, SH., SosPol., MSi.

\begin{abstract}
Abstrak:
Pada saat ini, penguasaan tanah oleh masyarakat hukum adat cenderung untuk ditinggalkan. Kondisi ini disebabkan oleh kebijakan pemerintah yang tidak memperhatikan perkembangan penguasaan tanah oleh masyarakat hukum adat. Kedudukan masyarakat hukum adat pada dasarnya diakui, selama tidak bertentangan dengan kepentingan umum. Oleh karena itu seharusnya negara dan pemerintah memberikan perlindungan terhadap hak masyarakat hukum adat sebagai kearifan lokal yang tercantum dalam konstitusi negara. Keberadaan hukum adat tidak pernah akan mundur atau tergeser dari dunia politik dalam membangun hukum nasional mengingat hukum adat memiliki kemampuan untuk menyesuaikan diri dan fleksibel.
\end{abstract}

\section{PENDAHULUAN}

Hukum adat adalah sistem hukum yang dikenal dalam lingkungan kehidupan sosial di Indonesia dan negara-negara Asia lainnya seperti Jepang, India, dan Tiongkok. Sumbernya adalah peraturan hukum tidak tertulis yang tumbuh dan berkembang dan dipertahankan dengan kesadaran hukum masyarakatnya. Karena peraturan-peraturan ini tidak tertulis dan tumbuh berkembang, maka hukum adat memiliki kemampuan untuk menyesuaikan diri dan fleksibel
Keberadaan hukum adat tidak pernah akan mundur atau tergeser dari dunia politik dalam membangun hukum nasional, hal terlihat dari terwujudnya ke dalam hukum nasional yaitu dengan mengangkat hukum rakyat atau hukum adat menjadi hukum nasional serta terlihat pada naskah sumpah pemuda pada tahun 1928 bahwa hukum adat layak diangkat menjadi hukum nasional yang modern.Menurut Soepomo, Hukum Adat adalah "Suatu hukum yang hidup karena ia menjelmakan perasaan hukum yang nyata dari rakyat". (Soepomo 2004). 
Dalam berbagai seminar, maka berkembang kemudian hukum yang hidup dalam masyarakat (living law) yang lazim dipergunakan untuk, menunjukkan berbagai macam hukum yang tumbuh dan berkembang dengan sendirinya di dalam masyarakat, yang menurut Rahardjo, akan tetap ada sebagai kelengkapan dari Hukum Nasional. Penyebutan Hukum Adat untuk hukum yang tidak tertulis tidak mengurangi peranannya dalam memberikan penyaluran dari kebiasaan, kepentingan-kepentingan yang tidak terucapkan dalam hukum tertulis.(Rahardjo 2006).

Dengan demikian sifat dan corak hukum adat timbul dan menyatu dalam kehidupan masyarakatnya, karena hukum hanya akan efektif dengan kultur dan corak masyarakatnya. Oleh karena itu pola pikir dan paradigma berfikir adat sering masih mengakar dalam kehidupan masyarakat sehari-hari sekalipun ia sudah memasuki kehidupan dan aktifitas yang disebut modern. Dapat diketahui bahwa dari 19 daerah lingkungan hukum (rechtskring) di Indonesia, sistem hukum adat dibagi dalam tiga kelompok, yaitu: (Soepomo: 2004)

\section{Hukum Adat mengenai tata negara}

2. Hukum Adat mengenai warga (hukum pertalian sanak, hukum tanah, hukum perhutangan).

3. Hukum Adat mengenai delik (hukum pidana).

Di dalam Hukum Adat, tanah merupakan masalah yang sangat penting. Hubungan antara manusia dengan tanah sangat erat, bahwa tanah sebagai tempat manusia untuk menjalani dan melanjutkan kehidupannya. Tanah adat merupakan milik dari masyarakat hukum adat yang telah dikuasai sejak dulu. Dinegara yang rakyatnya berhasrat melaksanakan demokrasi yang berkeadilan sosial, pemanfaatan tanah untuk sebesar-besar kemakmuran rakyat merupakan suatu conditio sine qua non. Untuk mencapai tujuan tersebut, diperlukan campur tangan penguasa yang berkompeten dalam urusan tanah, khususnya mengenai lahirnya, berpindah dan berakhirnya hak milik atas tanah.

Adanya hak atas tanah kemudian akan berpengaruh kepada suatu kelompok masyarakat yang paling sering mengalami masalah tanah yaitu masyarakat adat. Keberadaan masyarakat adat berikut hukum adat yang mengikuti dibelakang mereka kembali naik ke permukaan diawali dengan keberadaan beberapa peraturan yang memberikan tempat yang layak bagi mereka. Bermula dari keberadaan Undang-Undang tentang Pemerintah Daerah (UU No. 22 tahun 1999, LN 1999 No. 60 TLN 3839) yang kemudian memberikan kecenderungan bagi daerah-daerah untuk "mengatur" Sumber Daya Alam daerah mereka masing-masing, termasuk masalah tanah dan hukum adat yang berlaku bagi masyarakat tersebut. Tentunya kondisi ini pada akhirnya akan berpengaruh pada eksistensi masyarakat adat di masingmasing daerah tersebut.

Ketentuan tersebut mendapatkan alas hukum yang sangat kuat dengan diamandemennya UUD 1945 dalam beberapa pasalnya yang mengakui hak masyarakat adat tersebut, diantaranya Pasal 18 B (2) yang berbunyi: "Negara mengakui dan menghormati kesatuankesatuan masyarakat hukum adat beserta hak-hak tradisionalnya sepanjang masih hidup dan sesuai dengan perkembangan masyarakat dan prinsip negara kesatuan Republik Indonesia yang diatur dalam UU". 
Juga pada Pasal 28 I (3) yang merumuskan bahwa "Identitas budaya dan hak masyarakat tradisional dihormati selaras dengan perkembangan zaman dan peradaban". Serta beberapa pasal lainnya yang mengindikasikan pengakuan "kembali" keberadaan masyarakat adat tersebut.

Terlepas dari hal tersebut diatas itu, diseluruh Indonesia terdapat adanya hubungan antara persekutuan hukum dengan tanah dalam wilayahnya, atau dengan kata lain, persekutuan hukum itu mempunyai hak atas tanah-tanah tersebut, yang dinamakan Beschikkingsrecht. Untuk istilah ini, beberapa sarjana memiliki beberapa perbedaan penggunaan istilah, misalnya "Hak pertuanan" (Soepomo), "Hak ulayat"(Soekanto). Hal tersebut menurut Mahadi membuat suatu pemahaman bahwa tanah adat atau hukum tanah adat di Indonesia mempunyai pengaruh yang sangat besar dalam pola hidup dalam persekutuan masyarakat hukum adat. Tetapi masalah hukum tanah adat tidaklah mudah, karena masih di bawah pengaruh dualisme hukum tanah yang ada selama masa Pemerintah Hindia Belanda.(Mahadi 1994).

Bertitik tolak dari penjelasan tersebut diatas, maka dapat dilihat adanya dualisme hukum adat di Indonesia. Sifat seperti ini adalah hal yang perlu dihindari dalam lapangan hukum, sebab sifat dualisme dapat menimbulkan ketidak pastian hukum, suatu keadaan yang bertentangan dengan falsafah dan tujuan hukum itu sendiri. Selain itu, di Indonesia sudah terdapat peraturan perundangundangan yang mengatur tentang pertanahan, yaitu Undang-Undang Nomor 5 tahun 1960 tentang Pokok Pertanahan (UUPA 1960). Undang-Undang tersebut diciptakan untuk mengadakan unifikasi hukum pertanahan nasional. Sehingga, muncul beberapa pertanyaan, antara lain adalah "Bagaimana pengaturan hukum tanah adat yang ada di Indonesia? dan Bagaimana kedudukan hukum tanah adat (atau tanah adat) setelah berlakunya UUPA 1960?"

Dengan adanya fenomena tersebut diatas, mengarahkan pada kemungkinan adanya keberagaman dari ketentuan hukum yang mengatur masalah tanah, apabila dikaitkan dengan masyarakat dan hukum adat. Pada saat ini, apabila dilihat dari pengaturan pasal-pasal dalam UUD 1945 dan rencana akan dibuatnya Undangundang khusus mengenai hukum adat maupun masyarakat adat menunjukkan bahwa arus gelombang politik hukum mengenai pengaturan tanah saat ini adalah kepada keberagaman. Meskipun kondisi keberagaman ini belum langsung menjamin adanya perlindungan hukum terhadap tanah milik masyarakat adat, namun paling tidak memberikan harapan bagi masyarakat adat untuk diakuinya hukum adat serta hak mereka terhadap tanah adat mereka, yang akhir-akhir ini terancam hilang, mengingat pemerintah tidak akan segan "merampasnya"

\section{PERMASALAHAN}

Dengan melihat latar belakang tersebut diatas, maka dapat dirumuskan permasalahan sebagai berikut :

1. Bagaimana pengaturan hukum tanah adat yang ada di Indonesia berkaitan dengan eksistensi masyarakat adat? dan

2. Bagaimana eksistensi atau kedudukan hukum tanah adat? 
Hukum adat adalah sistem hukum yang dikenal dalam lingkungan kehidupan sosial di Indonesia dan negara-negara Asia lainnya seperti Jepang, India, dan Tiongkok. Sumbernya adalah peraturan hukum tidak tertulis yang tumbuh dan berkembang dan dipertahankan dengan kesadaran hukum masyarakatnya. Karena peraturan-peraturan ini tidak tertulis dan tumbuh berkembang, maka hukum adat memiliki kemampuan untuk menyesuaikan diri dan fleksibel. Keberadaan hukum adat tidak pernah akan mundur atau tergeser dari dunia politik dalam membangun hukum nasional, hal terlihat dari terwujudnyakedalam hukum nasional yaitu dengan mengangkat hukum rakyat atau hukum adat menjadi hukum nasional serta terlihat pada naskah sumpah pemuda pada tahun 1928 bahwa hukum adat layak diangkat menjadi hukum nasional yang modern.

Menurut Soepomo, Hukum Adat adalah "Suatu hukum yang hidup karena ia menjelmakan perasaan hukum yang nyata dari rakyat". (Soepomo 2004). Dalam berbagai seminar, maka berkembang kemudian hukum yang hidup dalam masyarakat (living law) yang lazim dipergunakan untuk, menunjukkan berbagai macam hukum yang tumbuh dan berkembang dengan sendirinya di dalam masyarakat, yang menurut Rahardjo, akan tetap ada sebagai kelengkapan dari Hukum Nasional. Penyebutan Hukum Adat untuk hukum yang tidak tertulis tidak mengurangi peranannya dalam memberikan penyaluran dari kebiasaan, kepentingan-kepentingan yang tidak terucapkan dalam hukum tertulis.(Rahardjo 2006).

Dengan demikian sifat dan corak hukum adat timbul dan menyatu dalam kehidupan masyarakatnya, karena hukum hanya akan efektif dengan kultur dan corak masyarakatnya. Oleh karena itu pola pikir dan paradigma berfikir adat sering masih mengakar dalam kehidupan masyarakat sehari-hari sekalipun ia sudah memasuki kehidupan dan aktifitas yang disebut modern. Dapat diketahui bahwa dari 19 daerah lingkungan hukum (rechtskring) di Indonesia, sistem hukum adat dibagi dalam tiga kelompok, yaitu: (Soepomo: 2004)

1. Hukum Adat mengenai tata negara

2. Hukum Adat mengenai warga (hukum pertalian sanak, hukum tanah, hukum perhutangan).

3. Hukum Adat mengenai delik (hukum pidana).

Di dalam Hukum Adat, tanah merupakan masalah yang sangat penting. Hubungan antara manusia dengan tanah sangat erat, bahwa tanah sebagai tempat manusia untuk menjalani dan melanjutkan kehidupannya. Tanah adat merupakan milik dari masyarakat hukum adat yang telah dikuasai sejak dulu. Dinegara yang rakyatnya berhasrat melaksanakan demokrasi yang berkeadilan sosial, pemanfaatan tanah untuk sebesar-besar kemakmuran rakyat merupakan suatu conditio sine qua non. Untuk mencapai tujuan tersebut, diperlukan campur tangan penguasa yang berkompeten dalam urusan tanah, khususnya mengenai lahirnya, berpindah dan berakhirnya hak milik atas tanah.

Adanya hak atas tanah kemudian akan berpengaruh kepada suatu kelompok masyarakat yang paling sering mengalami masalah tanah yaitu masyarakat adat. Keberadaan masyarakat adat berikut hukum adat yang mengikuti dibelakang mereka kembali naik ke permukaan 
diawali dengan keberadaan beberapa peraturan yang memberikan tempat yang layak bagi mereka. Bermula dari keberadaan Undang-Undang tentang Pemerintah Daerah (UU No. 22 tahun 1999, LN 1999 No. 60 TLN 3839) yang kemudian memberikan kecenderungan bagi daerah-daerah untuk "mengatur" Sumber Daya Alam daerah mereka masing-masing, termasuk masalah tanah dan hukum adat yang berlaku bagi masyarakat tersebut. Tentunya kondisi ini pada akhirnya akan berpengaruh pada eksistensi masyarakat adat di masingmasing daerah tersebut.

Ketentuan tersebut mendapatkan alas hukum yang sangat kuat dengan diamandemennya UUD 1945 dalam beberapa pasalnya yang mengakui hak masyarakat adat tersebut, diantaranya Pasal 18 B (2) yang berbunyi: "Negara mengakui dan menghormati kesatuankesatuan masyarakat hukum adat beserta hak-hak tradisionalnya sepanjang masih hidup dan sesuai dengan perkembangan masyarakat dan prinsip negara kesatuan Republik Indonesia yang diatur dalam UU". Juga pada Pasal 28 I (3) yang merumuskan bahwa "Identitas budaya dan hak masyarakat tradisional dihormati selaras dengan perkembangan zaman dan peradaban". Serta beberapa pasal lainnya yang mengindikasikan pengakuan "kembali" keberadaan masyarakat adat tersebut.

Terlepas dari hal tersebut diatas itu, diseluruh Indonesia terdapat adanya hubungan antara persekutuan hukum dengan tanah dalam wilayahnya, atau dengan kata lain, persekutuan hukum itu mempunyai hak atas tanah-tanah tersebut, yang dinamakan Beschikkingsrecht. Untuk istilah ini, beberapa sarjana memiliki beberapa perbedaan penggunaan istilah, misalnya "Hak pertuanan"(Soepomo), "Hak ulayat"(Soekanto). Hal tersebut menurut Mahadi membuat suatu pemahaman bahwa tanah adat atau hukum tanah adat di Indonesia mempunyai pengaruh yang sangat besar dalam pola hidup dalam persekutuan masyarakat hukum adat. Tetapi masalah hukum tanah adat tidaklah mudah, karena masih di bawah pengaruh dualisme hukum tanah yang ada selama masa Pemerintah Hindia Belanda.(Mahadi 1994).

Bertitik tolak dari penjelasan tersebut diatas, maka dapat dilihat adanya dualisme hukum adat di Indonesia. Sifat seperti ini adalah hal yang perlu dihindari dalam lapangan hukum, sebab sifat dualisme dapat menimbulkan ketidak pastian hukum, suatu keadaan yang bertentangan dengan falsafah dan tujuan hukum itu sendiri. Selain itu, di Indonesia sudah terdapat peraturan perundangundangan yang mengatur tentang pertanahan, yaitu Undang-Undang Nomor 5 tahun 1960 tentang Pokok Pertanahan (UUPA 1960). Undang-Undang tersebut diciptakan untuk mengadakan unifikasi hukum pertanahan nasional. Sehingga, muncul beberapa pertanyaan, antara lain adalah "Bagaimana pengaturan hukum tanah adat yang ada di Indonesia? dan Bagaimana kedudukan hukum tanah adat (atau tanah adat) setelah berlakunya UUPA 1960?"

Dengan adanya fenomena tersebut diatas, mengarahkan pada kemungkinan adanya keberagaman dari ketentuan hukum yang mengatur masalah tanah, apabila dikaitkan dengan masyarakat dan hukum adat. Pada saat ini, apabila dilihat dari pengaturan pasal-pasal dalam UUD 1945 dan rencana akan dibuatnya Undangundang khusus mengenai hukum adat 
maupun masyarakat adat menunjukkan bahwa arus gelombang politik hukum mengenai pengaturan tanah saat ini adalah kepada keberagaman. Meskipun kondisi keberagaman ini belum langsung menjamin adanya perlindungan hukum terhadap tanah milik masyarakat adat, namun paling tidak memberikan harapan bagi masyarakat adat untuk diakuinya hukum adat serta hak mereka terhadap tanah adat mereka, yang akhir-akhir ini terancam hilang, mengingat pemerintah tidak akan segan "merampasnya".

\section{PENGERTIAN HUKUM ADAT}

Hukum adat merupakan istilah tekhnik ilmiah, yang menunjukkan aturan-aturan kebiasaan yang berlaku di kalangan masyarakat yang tidak berbentuk peraturan-perundangan serta dibentuk oleh pemerintahan. Adapun terdapat beberapa definisi hukum adat yang dikemukakan para ahli hukum, antara lain sebagai berikut :

1. Van Vollenhoven, yang pertama kali menyebut hukum adat dan memberikan definisi hukum adat sebagai: "Himpunan peraturan tentang perilaku yang berlaku bagi orang pribumi dan timur asing pada satu pihak yang mempunyai sanksi (karena bersifat hukum) dan pada pihak lain berada dalam keadaan tidak dikodifikasikan (karena adat)".(Vollenhoven 2008)

2. Soepomo, merumuskan bahwa "Hukum adat adalah sinonim dari hukum yang tidak tertulis di dalam peraturan legislatif (statuary law), hukum yang hidup sebagai konvensi di badan-badan hukum Negara (Parlemen, Dewan Propinsi dan sebagainya), dan hukum yang hidup sebagai peraturan kebiasaan yang dipertahankan di dalam pergaulan hidup, baik di kota maupun di desadesa.(Soepomo: 2004)

3. Soekanto, merumuskan hukum adat adalah "Komplek adat inilah yang kebanyakan tidak dikitabkan, tidak dikodifikasikan dan bersifat paksaan mempunyai sanksi (dari itu hukum), jadi mempunyai akibat hukum, komplek ini disebut Hukum Adat."(Soekanto:2008)

4. Wignyodipuro: Hukum adat adalah suatu kompleks norma-norma yang bersumber pada perasaan keadilan rakyat yang selalu berkembang serta meliputi peraturan tingkah laku manusia dalam kehidupan sehari-hari dalam masyarakat, sebagian besar tidak tertulis, karena mempunyai akibat hukum (sanksi). (Wignyodipuro 1998)

Dengan mengkaji pengertian hukum adat dari berbagai sudut pandang tersebut diatas, yang menunjukkan apa yang disebut hukum adat, akan menentukan bagaimana hukum adat dalam perkembangannya, dan hukum adat akan mampu menyesuaikan dengan kebutuhan dan tuntutan dalam masyarakat yang akan terus berubah. Oleh karena itu pemahaman pengertian, pendekatan metodologis menjadi penting sekali untuk dapat melihat, memahami dan mempelajari perkembangan hukum adat atau hukum adat dalam perkembangannya. Dengan demikian pengertian hukum adat ialah endapan(renapan) kesusilaan dalam masyarakat, artinya kaedah-kaedah adat berupa kaedah kesusilaan yang kebenarannya telah mendapat pengakuan umum dalam masyarakat. 


\section{DEFINISI HUKUM TANAH ADAT}

Seperti yang telah dijelaskan diatas, tanah sangat diperlukan oleh anggota masyarakat, oleh karena itu diperlukan kaedah-kaedah yang mengatur hubungan antara manusia dengan tanah. Hukum tanah adalah keseluruhan kaedah hukum yang tumbuh dari pergaulan hidup antar manusia yang berhubungan dengan pemanfaatan mengenai masalah tanah. Dalam hukum tanah adat terdapat kaedahkaedah hukum. Keseluruhan kaedah hukum yang tumbuh dan berkembang didalam pergaulan hidup antar sesama manusia adalah sangat berhubungan erat tentang pemanfaatan sekaligus menghindarkan perselisihan tanah sebaikbaiknya. Hal inilah yang diatur di dalam hukum tanah adat. Dari ketentuanketentuan hukum tanah ini akan timbul hak dan kewajiban yang berkaitan erat dengan hak-hak yang ada diatas tanah.

Seperti yang telah dijelaskan, bahwa tanah adalah tempat untuk mencari nafkah, mendirikan rumah atau tempat kediaman, dan juga menjadi tempat dikuburnya orang pada waktu meninggal. Artinya, tanah adalah hal yang sangat diperlukan manusia. Supaya tidak ada ketidak-jelasan hak antara satu sama lain pihak, maka diperlukan aturan-aturan yang mengatur hubungan antara manusia dengan tanah. Aturan-aturan atau kaedah-kaedah yang mengatur hubungan manusia dengan tanah ini, selanjutnya disebut hukum tanah menurut hukum adat.

Menurut Marwan dan Prastowo, hukum adat di Indonesia ada 2 (dua) macam hak yang timbul atas tanah, antara lain yaitu: (Marwan and Prastowo 1990)

1. Hak persekutuan, yaitu hak yang dimiliki, dikuasai, dimanfaatkan, dinikmati, diusahakan oleh sekelompok manusia yang hidup dalam suatu wilayah tertentu yang disebut dengan masyarakat hukum (persekutuan hukum). Lebih lanjut, hak persekutuan ini sering disebut dengan hak ulayat, hak dipertuan, hak purba, hak komunal, atau beschikingsrecht.

2. Hak Perseorangan, yaitu hak yang dimiliki, dikuasai, dimanfaatkan, dinikmati, diusahakan oleh seseorang anggota dari persekutuan tertentu.

Hak atas tanah yang ada lebih dahulu adalah hak persekutuan, karena awalnya manusia hidup nomaden, maka pada saat itu :

1. Semua anggota kelompok merasa berhak terhadap semua bidang tanah dalam wilayah pengembaraan.

2. Semua anggota merasa berhak untuk memungut hasil dari semua bidang tanah dalam wilayah engembaraan.

3. Hak perseorangan belum ada, baru muncul setelah masyarakat mulai menetap, sehingga hak perseorangan tertumpang di atas hak persekutuan, seperti hak sewa yang tertumpang di atas hak milik. (Marwan dan Prastowo 1990).

Dengan dikuasainya tanah oleh persekutuan dan warganya, terjadi hubungan hukum (hak) antara persekutuan dengan tanah yang 
kemudian diikuti dengan munculnya hak perseorangan. Pola-pola hubungan antara persekutuan atau individu dengan tanah yang dikuasainya disebut hukum tanah adat. Hubungan hukum adalah hubungan yang bersifat abstrak antara subyek hukum dengan obyek hukum atau antar subyek hukum yang dapat dipertahankan melalui prosedur hukum, karena oleh masyarakat disediakan wadah dan prosedur mempertahankannya. Isi hubungan hukum itu adalah hak dan atau kewajiban

(Zakelijkrecht

Persoonlijkrecht).

\section{GAMBARAN UMUM MASYARAKAT HUKUM ADAT}

Masyarakat (society) adalah suatu sistem sosial yang menghasilkan kebudayaan. Poerwadarminta menyebutkan: "Masyarakat adalah pergaulan hidup manusia (himpunan orang yang hidup bersama dalam sesuatu tempat dengan ikatan-ikatan yang tertentu). Masyarakat adalah sekelompok orang yang mempunyai identitas sendiri, yang membedakan dengan kelompok lain dan hidup dan diam dalam wilayah atau daerah tertentu secara tersendiri. Kelompok ini baik sempit maupun luas mempunyai perasaan akan adanya persatuan di antara anggota kelompok dan menganggap dirinya berbeda dengan kelompok lain. Mereka memiliki normanorma, ketentuan-ketentuan dan peraturan yang dipatuhi bersama sebagai suatu ikatan. Perangkat dan pranata tersebut dijadikan pedoman untuk memenuhi kebutuhan kelompok dalam arti luas. Jadi secara luas bahwa dalam masyarakat terdapat semua bentuk pengorganisasian yang diperlukan untuk kelangsungan hidupnya (masyarakat tersebut)". (Poerwadarminta 1990).

Lingkungan masyarakat adalah suatu bagian dari suatu lingkungan hidup yang terdiri atas antar hubungan individu dengan kelompok dan pola-pola organisasi serta segala aspek yang ada dalam masyarakat yang lebih luas dimana lingkungan sosial tersebut merupakan bagian dari padanya. Lingkungan sosial dimaksud dapat terwujud sebagai kesatuan-kesatuan sosial atau kelompokkelompok sosial, tetapi dapat juga terwujud sebagai situasi-situasi sosial yang merupakan sebagian dari dan berada dalam ruang lingkup suatu kesatuan atau kelompok sosial. Di dalam masyarakat terdapat struktur sosial yaitu pola hak dan kewajiban para pelaku dalam suatu sistem interaksi yang terwujud dari rangkaianrangkaian hubungan sosial yang relatif stabil dalam suatu jangka waktu tertentu. Sesuai dengan penggolongan dalam kebudayaan yang bersangkutan dan yang berlaku menurut masing-masing pranata dan situasi-situasi sosial dimana interaksi sosial itu terwujud.

Secara empiris hampir setiap daerah (provinsi dan kabupaten) di Indonesia, dapat ditemukan masyarakat hukum adat. Mereka dicirikan dengan sekelompok orang yang terikat oleh tatanan hukum adatnya sebagai warga bersama suatu persekutuan hukum karena kesamaan tempat tinggal ataupun dasar keturunan. Secara empiris mereka mendiami daerah yang secara geografis terpencil dan sulit dijangkau, tidak terjangkau oleh pelayanan sosial dasar, dan sumber penghidupannya sangat bergantung pada alam. Mereka hidup dalam berbagai keterbatasan untuk memenuhi kebutuhan sosial dasar, seperti sandang, pangan, tempat tinggal, kesehatan dan pendidikan. Mereka mengkonsumsi makanan jauh dari 
strandar gizi yang diajurkan, memakai pakaian yang tidak pantas, menempati rumah yang tidak layak huni, kesehatan yang memburuk dan tidak bisa berpartisipasi dalam pendidikan. Oleh karena keterbatasannya dalam memenuhi kebutuhan sosial dasar tersebut, maka mereka mengalami hambatan untuk dapat menjaga kelangsungan hidupnya atau angka kematian pada mereka relatif cukup tinggi.(Manurung 2006).

Dalam kondisi yang senantiasa diliputi keterbatasan tersebut, masyarakat hukum adat dihadapkan dengan berbagai permasalahan, seperti semakin berkurangnya ruang gerak mereka disebabkan menyempitnya tanah ulayat yang pindah ke tangan investor. Salah satu contoh seperti di Provinsi Riau maupun di Provinsi Sumatera Utara, masyarakat hukum adat banyak kehilangan tanah ulayatnya karena diolah oleh PTP untuk perkebunan karet dan kelapa sawit. Kemudian sebagian hutan tempat tinggal masyarakat hukum adat berubah fungsi menjadi hutan lindung, dimana dengan penetapan sebagai hutan lindung berarti siapapun dilarang untuk memasuki hutan tersebut.

Masyarakat hukum adat rentan menjadi korban eksploitasi dan atau perdagangan manusia untuk kepentingan pengusaha hutan. Pengusaha hutan memanfaatkan kebodohan mereka untuk kepentingannya seperti dalam penebangan liar (illegal loging).Kondisi tersebut ditambah lagi dengan semakin kuatnya pengaruh dari luar yang merusak nilai-nilai dan kearifan lokal yang selama ini dipelihara secara turun temurun. Lemahnya peraturan pemerintah yang mengatur eksistensi dan hak-hak masyarakat hukum adat, menyebabkan aturan-aturan adat tidak dihormati dan dihargai oleh orang-orang dari luar.
Meskipun masyarakat hukum adat dihadapkan dengan berbagai keterbatasan dan permasalahan, tetapi mereka sangat kurang disentuh oleh program-program pemerintah. Alasannya karena mereka mendiami lokasi yang secara geografis terpencil dan sangat sulit dijangkau, seperti di pedalaman, rawa-rawa, pegunungan dan perbatasan antar negara, dan di perairan. Selain itu, sebagian masyarakat hukum adat masih memiliki pola hidup berpindah-pindah dari satu tempat ke tempat lain yang jaraknya cukup jauh (nomaden). Oleh karena tidak terjangkau program pemerintah, maka sebagian dari mereka yang mendiami kawasan perbatasan antar Negara, seperti masyarakat hukum adat di Kalimantan Timur, Kalimantan Barat, NTT, Papua dan Kepri; menjadi pelintas batas antar Negara yang tujuannya semata-mata untuk kelangsungan hidup. Terjadinya pelintas batas antar Negara ini tentu akan menimbulkan persoalan hubungan antar Negara.

Dari sisi kemanusiaan, kondisi yang dihadapi oleh masyarakat hukum adat yang tersebar di 30 Provinsi di Indonesia, benar - benar sangat memprihatinkan. Mereka sangat membutuhkan dukungan, perlindungan dan pemberdayaan dari pemerintah untuk dapat meningkatkan harkat dan martabatnya. Sebagai warga bangsa, mereka merindukan hak-haknya atas hidup, kesejahteraan dan hak ulayat atas tanah.(Akbar 2005). Berdasarkan kondisi faktual masyarakat hukum adat, maka kebijakan dan program kesejahteraan sosial bagi mereka merupakan suatu keharusan, sebagai wujud tanggung jawab Negara dan Pemerintah. Mereka adalah warga Negara (sebagaimana 
warga Negara Indonesia pada umumnya) yang memiliki hak untuk hidup sejahtera dan berpartisipasi dalam pembangunan.

\section{PENGATURAN HUKUM TANAH ADAT YANG ADA DI INDONESIA}

Seperti yang telah dijelaskan diatas, hak atas tanah ada dua macam :

1. Hak persekutuan ( hak ulayat)

2. Hak perseorangan

Hak Persekutuan Atas Tanah adalah kewenangan persekutuan hukum adat atas setiap jengkal tanah yang ada dalam wilayah persekutuan seperti :

1. Kewenangan persekutuan untuk memanfaatkan bidang tanah tertentu untuk keperluan persekutuan, kantor lembaga adat, tempat ibadah, jalan, saluran irigasi, dsb.

2. Kewenangan persekutuan untuk mengatur pencadangan dan pemanfaatan semua bidang tanah dalam wilayah persekutuan.

3. Kewenangan persekutuan untuk mengizinkan warga persekutuan membuka/mengolah/memanfaatkan sebidang tanah tertentu, sehingga warga itu memperoleh hak perorangan.

4. Kewenangan persekutuan untuk mengurus dan mengatur peralihan bidang tanah dalam wilayah persekutuan, baik antar warga persekutuan, maupun dengan pihak luar.

Sedangkan untuk Hak Persorangan Atas Tanah adalah kewenangan dari anggota persekutuan atas bidang tanah tertentu dari wilayah persekutuan dengan memungut hasil seperti: mengambil kayu, rotan, damar, gaharu, ikan, binatang liar, dalam wilayah persekutuannya.

Dengan izin persekutuan, mereka dapat membuka dan mengusahakan terus menerus bidang tanah tertentu dalam wilayah persekutuan seperti pemukiman, sawah, tambak, toko, dsb. Selain itu, melakukan transaksi tanah dan transaksi yang berhubungan dengan tanah dengan berbagai pihak. Pada waktu seorang warga persekutuan atas izin persekutuan membuka dan mengurus terus menerus bidang tanah tertentu, hak ulayat persekutuan menipis (tapi tetap ada) hak perorangan menonjol. Bila tanah diterlantarkan, hak persekutuan penuh kembali. Adapun jenis transaksi atas tanah mencakup, Jual Beli Tanah, Hibah Tanah, Tukar Menukar Tanah, Wakaf Tana. Transaksi Yang berhubungan dengan tanah, Pinjam meminjam tanah, Gadai tanah (jual gadai, Sewa menyewa tanah (jual tahunan dan sewa), Bagi hasil tanah. Sedangkan pengaruh Luar terhadap hukum tanah adat antara lan, Pengaruh hukum Islam, Pengaruh hukum kolonial Belanda, Pengaruh Perundangan RI.

Ada banyak perbedaan prinsip antara hukum tanah adat regional dan hukum agraria nasional, yang tentu saja dapat menimbulkan konflik yang cukup serius. Pada Undang-undang Pokok Agraria 1960 (UUPA-1960), hukum adat dijadikan landasannya, sedangkan hak ulayat merupakan salah satu dari lembagalembaga hukum adat dan kemudian dikembangkan kepada fungsi sosial dari hak-hak atas tanah.

Pasal 5 UUPA mengatur bahwa: "Hukum Agraria yang berlaku atas bumi, air dan ruang angkasa ialah hukum adat, sepanjang tidak bertentangan dengan 
kepentingan nasional dan negara, yang berdasarkan atas persatuan bangsa, dengan sosialisme Indonesia serta dengan peraturan-peraturan yang tercantum dalam undang- undang inidan dengan peraturan perundangan lainnya, segala sesuatu dengan mengindahkan unsur-unsur yang bersandar pada hukum agama."

Lebih dari pada itu, dalam mukadimah UUPA 1960 menyatakan bahwa "Berhubungan dengan apa yang tersebut dalam pertimbangan-pertimbangan di atas perlu adanya Hukum Agraria Nasional, yang berdasar atas hukum adat tentang tanah, yang sederhana dan menjamin kepastian hukum bagi seluruh rakyat Indonesia, dengan tidak mengabaikan unsur-unsur yang bersandar pada hukum agama". Dengan demikian, dengan berlakunya UUPA 1960, akan meniadakan dualisme hukum pertanahan dengan menundukkan kembali hukum adat pada tempatnya sebagai landasan utama hukum agraria nasional. Namun. Perlu diingat bahwa hukum agraria nasional itu, berdasarkan atas hukum adat tanah, yang bersifat nasional, bukan hukum adat yang bersifat kedaerahan atau regional. Artinya, untuk menciptakan hukum agraria nasional, maka hukum adat yang ada di seluruh penjuru nusantara, dicarikan format atau bentuk yang umum dan berlaku bagi seluruh persekutuan adat. Tentu saja, tujuannya adalah untuk meminimalisir konflik pertanahan dalam lapangan hukum tanah adat.

Untuk itu, dalam substansi Pasal 5 UUPA 1960 dapat ditarik kesimpulan, bahwa: (Prof.Dr.AP. PARLINDUNGAN 1998)

"Hukum adat yang berlaku dalam bidang pertanahan atau agraria adalah yang terhadap kepentingan nasional (prinsip nasionalitas), pro kepada kepentingan negara, pro kepada sosialisme Indonesia, tidak bertentangan dengan undang-undang atau peraturan yang lebih tinggi, dan ditambah dengan unsur agama".

Jadi, motivasi dari hukum agraria nasional, dalam hal ini UUPA 1960 sebagai induknya, benar-benar akan mengurangi konflik pertanahan yang dapat timbul sebagai akibat penerapan hukum tanah adat yang bersifat kedaerahan. Hukum agraria nasional tidak hanya tercantum dalam UUPA 1960 saja, tetapi juga terdapat dalam peraturan perundangundangan lainnya yang mengatur tentang perjanjian-perjanjian ataupun transaksitransaksi yang berhubungan dengan tanah. Misalnya, Undang-Undang Nomor 2 tahun 1960 tentang Perjanjian Bagi Hasil Pertanian, Undang-Undang Nomor 2 tahun 1960 tentang Penetapan Ceiling Tanah dan Gadai tanah pertanian.

Di sini dapat dilihat bahwa semua masalah hukum tanah adat secara praktis di akomodasi oleh peraturan perundangundangan yang dibuat oleh pemerintah (penguasa). Bahkan dalam UndangUndang Nomor 23 tahun 1997 tentang Pengelolaan Lingkungan Hidup (UU No.23 Tahun 1997), hukum adat juga dijadikan dasar penetapan dan pembentukannya. Dimana dalam Pasal 9 UU No.23 Tahun 1997 disebutkan bahwa pemerintah menetapkan Kebijaksanaan nasional tentang pengelolaan lingkungan hidup dan penataan ruang dengan tetap memperhatikan nilai-nilai agama, adat istiadat, dan lain-lain yang hidup dalam masyarakat. Permenag 5 tahun1999: Pasal 1 yaitu sebagai berikut:

1. Hak ulayat dan yang serupa itu dari masyarakat hukum adat (untuk selanjutnya disebut hak ulayat), adalah kewenangan yang menurut 
hukum adat dipunyai oleh masyarakat hukum adat tertentu atas wilayah tertentu yang merupakan lingkungan hidup para warganya untuk mengambil manfaat dari sumber daya alam, termasuk tanah, dalam wilayah tersebut, bagi kelangsungan hidup dan kehidupannya, yang0020timbul dari hubungan secara lahiriah dan batiniah turun menurun dan tidak terputus antara masyarakat hukum adat tersebut dengan wilayah yang bersangkutan.

2. Tanah Ulayat: Tanah ulayat adalah bidang tanah yang diatasnya terdapat hak ulayat dari suatu masyarakat hukum adat tertentu

3. Masyarakat hukum adat adalah sekelompok orang yang terikat oleh tatanan hukum adatnya sebagai warga bersama suatu persekutuan hukum karena kesamaan tempat tinggal ataupun atas dasar keturunan.

\section{EKSISTENSI ATAU KEDUDUKAN HUKUM TANAH ADAT}

Hukum tanah adat yang dibahas dalam pembahasan sebelumnya menunjukkan bahwa dengan adanya tanah persekutuan dan tanah perseorangan mempunyai fungsi sosial, yang serupa diatur dalam UUPA. 1960.Dapat diketahui bahwa peran pemerintah atau penguasa sangat menentukan untuk menciptakan suasana yang kondusif dalam bidang pertanahan, khususnya hukum tanah adat. Akan tetapi bertitik tolak dari peran Pemerintah tersebut, sering kali kebijakan-kebijakan bidang pertanahan atau agraria memilki tendensi politik dari pada dari hukumnya.

Oleh karena itu, prinsip mendahulukan kepentingan sosial dapat diartikan bahwa segala kebijaksanaan bidang pertanahan tidak boleh dibiarkan merugikan kepentingan masyarakat. Tanah tidak diperkenankan semata-mata untuk kepentingan pribadi atau kelompok, kegunaannya harus disesuaikan dengan keadaanya dan sifat dari haknya sehingga bermanfaat, baik untuk kesejahteraan dan kebahagiaan yang mempunyai, serta baik dan bermanfaat untuk masyarakat dan kepentingan negara.

Kepentingan masyarakat dan kepentingan perseorangan haruslah saling imbang mengimbangi, atau adil adanya. Salah satu hal yang dapat menjamin kepastian hukum bidang pertanahan adalah dengan melakukan pensertifikatan tanah adat. Pasal 19 UUPA 1960 menyatakan bahwa "Untuk menjamin kepastian hukum oleh Pemerintah diadakan pendaftaran tanah di Seluruh Wilayah Republik Indonesia menurut ketentuan-ketentuan yang diatur dengan peraturan Pemerintah".

Hukum Tanah Adat setelah berlakunya UUPA seperti yang telah dijelaskan dalam konsepsi UUPA, maka "Tanah, sebagaimana halnya juga dengan bumi, air dan ruang angkasa termasuk kekayaan alam yang terkandung didalamnya yang ada di wilayah Republik Indonesia, adalah karunia Tuhan Yang Maha Esa pada Bangsa Indonesia yang merupakan kekayaan nasional". Dalam Pasal 5 UUPA ada disebutkan bahwa "Hukum Agraria yang berlaku atas bumi, air dan ruang angkasa maksudnya Hukum Adat sepanjang tidak bertentangan dengan kepentingan Nasional dan Negara yang berdasarkan atas persatuan bangsa, dengan sosialisme Indonesia serta peraturanperaturan yang tercantum dalam undangundang ini dengan peraturan perundangan-undangan lainya, segala sesuatu dengan mengindahkan unsur- 
unsur yang bersandar pada hukum agama."

Adanya ketentuan tersebut diatas menimbulkan dua permasalahan terhadap hukum adat tentang tanah yang berlaku dalam masyarakat Indonesia, dimana di satu pihak ketentuan tersebut memperluas berlakunya hukum adat tidak hanya terhadap golongan Eropa dan Timur Asing. Hukum Adat di sini tidak hanya berlaku untuk tanah-tanah Indonesia saja akan tetapi juga berlaku untuk tanah-tanah yang sebelumnya termasuk dalam golongan tanah Barat. Setelah berlakunya ketentuan tersebut di atas, maka kewenangan berupa penguasaan tanahtanah oleh persekutuan hukum mendapatkan pembatasan sedemikian rupa dari kewenangan pada masa-masa sebelumnya karena sejak saat itu segala kewenangan mengenai persoalan tanah terpusat pada kekuasaan negara.

Dengan demikian kewenangan masyarakat hukum adat atas tanah yang disebut hak ulayat tersebut, belum pasti diakui berlakunya atau mengalami perubahan sebagaimana halnya dengan ketentuan-ketentuan hukum adat tentang tanah. Mengenai hal tersebut dapat dilihat dalam beberapa ketentuan dari UUPA, antara lain :

1. Pasal 2 ayat (4) "Hak menguasai dari Negara tersebut di atas pelaksanaannya dapat dikuasakan kepada daerah-daerah swantanra dan masyarakat-masyarakat hukum adat, sekedar diperlukan dan tidak bertentangan dengan kepentingan Nasional".

2. Peraturan Pemerintah Pasal 3 "Dengan menggugat ketentuanketentuan dalam Pasal 1 dan 2 pelaksanaan hak ulayat dan hak-hak yang serupa dari masyarakat hukum adat sepanjang menurut kenyataan masih ada harus sedemikian rupa sehingga sesuai dengan kepentingan Nasional dan Negara, yang berdasarkan atas persatuan bangsa serta tidak boleh bertentangan dengan undang-undang dan peraturanperaturan yang lebih tinggi".

3. Pasal 22 ayat (1) "Terjadinya hak milik menurut hukum adat diatur dengan peraturan Pemerintah".

Seperti yang telah disebutkan di atas, bahwa setelah berlakunya UUPA ini, tanah adat di Indonesia mengalami perubahan. Maksudnya segala sesuatu yang bersangkutan dengan tanah adat, misalnya hak ulayat, tentang jual beli tanah dan sebagainya, mengalami perubahan. Apabila sebelum berlakunya UUPA, hak ulayat masih milik persekutuan hukum adat setempat yang sudah dikuasai sejak lama dari nenek moyang mereka dahulu. Namun setelah berlakunya UUPA, hak ulayat masih diakui, karena hal ini dapat dilihat dari pasal 3 UUPA, "Hak ulayat dan hak-hak yang serupa dari masyarakat hukum adat masih diakui sepanjang dalam kenyataan di masyarakat masih ada".

Apabila terjadi proses individualis terhadap hak ulayat ini mulai mendesak, maka dapat memberikan pengakuan secara khusus terhadap hak-hak perorangan. Dengan tumbuh dan kuatnya hak-hak yang bersifat perorangan dalam masyarakat hukum adat mengakibatkan menipisnya hak ulayat. Hak ulayat ini diakui oleh Pemerintah sepanjang kenyataanya masih ada. Kalau sudah ada maka tidak perlu untuk membuat adanya hak ulayat baru. Hak ulayat yang diakui 
dalam pasal tersebut bukanlah hak ulayat seperti dengan masa sebelumnya dengan kepentingan Nasional dan negara perbatasan bahwa "Hak ulayat yang dimaksud tidak boleh bertentangan dengan undang-undang dan Peraturan-peraturan lainya".

Pada waktu sebelumnya, suatu bidang tanah yang sudah dibuka atas izin pemangku adat atau kepala adat yang berwenang, apabila beberapa tahun tidak dikerjakan/ditanami kembali atau terdapat belukar, maka dapat diberi peruntukan lain/baru kepada pihak yang membentuknya, akibat pengaruh lamanya waktu dan tanah itu telah kembali kepada hak ulayat desa. Dalam perjalanan waktu, apabila izin membuka tanah dan tanahnya tujuannya digunakan terus, maka pemegang hak itu tidak memerlukan izin lagi untuk menggunakan tanah secara terus menerus karena semakin lama seorang memanfaatkan hak/izin itu, maka bertambah kuat hak melekat di atasnya, sampai pada akhirnya menjadi hak milik. Hak milik juga mengalami perubahan, sebelum berlakunya UUPA, lazimnya didaftarkan dan dikenakan pajak hasil bumi.

Akan tetapi, pada era Republik pascakolonial ini eksistensi dan peran hukum adat dalam perkara pertanahan sudah tidak sekuat dahulu, ketika eksistensinya sampai batas tertentu masih memperoleh pengakuan justru oleh pemerintah kolonial. Apabila hukum perundangundangan kolonial masih mengakui hakhak individual orang-orang pribumi (sekalipun baru berupa hak ipso/de facto yang disebut bezitsrecht), dan mengakui pula hak-hakkolektif desa dan masyarakatmasyarakat hukum adat lainnya, lain halnya dengan Perundang-undangan Republik yang justru tidak demikian.
Pasal 33 ayat 2 UUD-45 yang menyatakan bahwa "Bumi, air, dan kekayaan yang terkandung di dalamnya dikuasai oleh negara" secara tidak langsung telah menjadi dasar pembenar konstitusional untuk memperkecil eksistensi dan kompetensi komunitas-komunitas lokal, dengan hukum adatnya, untuk menguasai bumi, air dan sumberdaya agraria lain yang berada di tempat.

\section{KESIMPULAN}

Negara dan Pemerintah mengakui dan menghargai eksistensi masyarakat hukum adat di Indonesia. Pengakuan dan penghargaan dari Negara dan Pemerintah tersebut dapat dicermati dari produk yuridis yang menjadi payung hukum program perlindungan dan pemberdayaan masyarakat hukum adat, baik oleh instansi Pemerintah sektoral maupun oleh organisasi sosial / LSM dan dunia usaha. Dari pihak masyarakat, perhatian terhadap masyarakat hukum adat terlihat dari berbagai upaya yang dilakukan oleh organisasi sosial / LSM dalam memperjuangkan hak - hak dasar masyarakat hukum adat, antara lain hak atas tanah ulayat, pendidikan, kesehatan dan kesejahteraan.

Pengakuan dan penghargaan terhadap masyarakat hukum adat tersebut menunjukkan adanya kesadaran, bahwa masih ada masyarakat Indonesia yang menjalani kehidupan yang khas, sarat dengan nilai-nilai, norma dan adat istiadat yang positif, tetapi dalam kondisi yang sangat memprihatinkan. Meskipun demikian, pada era transformasi sosial budaya yang cepat dewasa ini, mereka masih mampu mempertahankan keserasian hubungan dengan sesama manusia, alam dan penciptanya. Semua itu adalah bentuk kebudayaan menjadi 
modal sosial (social capital) dalam pembangunan nasional apabila dapat diberdayakan secara optimal.

Sehubungan dengan hal tersebut diatas, maka diperlukan kebijakan dan instrumen yang mampu melindungi dan memberdayakan masyarakat hukum adat tanpa mencabut mereka dari akar sosial budaya aslinya. Sebagaimana dikemukakan pada bab sebelumnya, bahwa secara yuridis Negara dan Pemerintah telah menerbitkan peraturan perundang-undangan yang secara langsung berkaitan dengan perlindungan dan pemberdayaan masyarakat hukum adat. Namun demikian, kehendak Negara dan Pemerintah tersebut belum diikuti oleh Pemerintah Provinsi maupun Kabupaten. Sebagian besar Pemerintah Provinsi maupun Kabupaten hingga saat ini belum memiliki Peraturan Daerah (Perda) atau Peraturan Gubernur/Bupati yang berkenaan dengan perlindungan dan pemberdayaan masyarakat hukum adat. Implikasi dari belum tersedianya peraturan perundang-undangan daerah tersebut, maka di lapangan masih seringkali terjadi permasalahan antara Pemerintah dengan masyarakat hukum adat yang berlarutlarut.

Di samping usaha-usaha Pemerintah untuk memberikan jaminan dan kepastian hak atas tanah masih ada kekhawatiran tertentu untuk gagasan pendaftaran tanah dan sertifikasi tanah adat, karena akan mengurangi kelestarian tanah-tanah adat tersebut sendiri. Akan tetapi dengan adanya pendaftaran tanah jelas bertujuan untuk memberikan kepastian hukum kepada pemegang hak dan demikian juga kepada objek, sehingga dapat dihindarkan persengketaan-persengketaan yang tidak perlu terjadi. Dengan mendaftarkan tanah adat berdasarkan peraturan perundangan sekaligus memperhatikan hukum tanah adat yang berlaku secara nasional, dan secara tidak langsung kita telah memberikan suatu tanda kepada tanah itu, mana yang bisa dialihkan, mana yang bisa diwariskan. Tentu saja usaha-usaha Pemerintah untuk menjaga agar jangan sampai ada penyimpangan dari ketentuan adat yang berlaku di bidang tanah, dimulai dengan surat tanda bukti penguasaan dan pemilikan tanah.

Selain itu juga harus diupayakan untuk menghilangkan birokrasi yang berbelitbelit dan ditekan sekecil mungkin segala biaya-biaya yang tidak jelas peruntukannya yang berhubungan dengan masalah tanah. Serta lembaga-lembaga pengkajian dan penelitian masalah hukum adat dan badan pemantau urusan pertanahan perlu diperbanyak keberadaannya yang bertujuan untuk menyusun kebijaksanaan politis dan hukum bidang agraria, agar tetap diperhatikannya hukum tanah adat yang berlaku secara nasional.

\section{DAFTAR PUSTAKA}

1. Akbar, Rizal. Tanah Ulayat dan Keberadaan Masyarakat Adat. Pekanbaru: LPNU Press, 2005.

2. Mahadi. Beberapa Sendi Hukum di Indonesia. Jakarta: Saksama, 1994.

3. Manurung, Butet. Sokola Rimba: Pengalaman Belajar Bersama Orang Rimba. Yogyakarta: Insist Press, 2006.

4. Marwan, Muchlis, and Andri Astuti Prastowo. Pengantar Hukum Adat (Hukum Adat). Surakarta: UNS, 1990. 
5. Poerwadarminta, W.J.S. Kamus Umum Bahasa Indonesia. Jakarta: PN. Balai Pustaka, 1990.

6. Prof.Dr.AP. PARLINDUNGAN, $\mathrm{SH}$. Komentar Atas Undang-Undang Pokok Agraria. Bandung: Mandar Maju, 1998.

7. Rahardjo, Satjipto. Ilmu Hukum, cetakan ke-6. Bandung: PT. Citra Aditya Bakti, 2006.

8. Soekanto, Soerjono. Hukum dalam Masyarakat: Perkembangan dan Masalah, Cet. ke-2. Malang: Bayumedia Publishing, 2008.

9. Soepomo. Hukum Acara Perdata Pengadilan Negeri (cetakan keenambelas). Jakarta: PT. Pradnya Paramita, 2004.

10. Vallenhoven, Prof. Van. Pengantar Ilmu Hukum. Jakarta: Perca, 2008.

11. Wignyodipuro, Soerojo. Pokok-pokok Hukum Adat. Jakarta: Gunung Agung, 1998. 